\title{
Synthesis and Antifungal Activity of Some New Fluorine-Substituted 4-Thiazolidinone Bearing 1,2,4-Triazinone
}

\author{
Layla A. Taib \\ Department of Chemistry, Faculty of Science, King Abdul-Aziz University, Jeddah, KSA \\ Email: laylataib@yahoo.com
}

How to cite this paper: Taib, L.A. (2018) Synthesis and Antifungal Activity of Some New Fluorine-Substituted 4-Thiazolidinone Bearing 1,2,4-Triazinone. International Journal of Organic Chemistry, 8, 170-175. https://doi.org/10.4236/ijoc.2018.81012

Received: January 31, 2018

Accepted: March 11, 2018

Published: March 14, 2018

Copyright $\odot 2018$ by author and Scientific Research Publishing Inc. This work is licensed under the Creative Commons Attribution International License (CC BY 4.0).

http://creativecommons.org/licenses/by/4.0/

\begin{abstract}
Fluorine substituted 4-thiazolidinone 5 bearing 1,2,4-triazinone obtained from the condensation of 3-Amino-6(2'-aminophenyl)-1,2,4-triazin-5(4H)-one (2) with an aromatic aldehyde followed by cycloaddition with mercaptoacetic acid afforded the thiazolidinone (4), and treatment with ethyl trifluoroacetate. Structure of the products has been deduced from their correct elemental analysis and spectral measurements. The antifungal activity of the new fluorinated target also has been evaluated.
\end{abstract}

\section{Keywords}

Synthesis, Fluorine , 4-Thiazolidinone, 1,2,4-Triazin Fungal

\section{Introduction}

The use of heterocycles as chemical fertilizers to increase the yield of crops and to eliminate all kinds of parasites able to attack the cultivation is becoming more important because of the great problem facing the world to provide food to an increasing population [1]. Among these heterocycles, (2-thioxo-thiazolidin-4-one) and its derivatives exhibit a wide spectrum in the medicinal, pharmacological and agricultural [2], as well as use for determination of $\mathrm{Cu}(\mathrm{II}), \mathrm{Hg}(\mathrm{II}), \mathrm{Cl}^{-}$and $\mathrm{CN}^{-}$ions in the industrial wastewater [3]. On the other hand, functionally 1,2,4-triazine derivatives have essential properties as medicinal, pharmacological and biological fields [4] [5] [6]. Also, the introduction of fluorine atom to the heterocyclic systems often enhances and improves their properties [7] [8] [9]. Based upon these observations, the present work reports synthesis of some new fluorine-substituted 4-thiazolidinone starting from 3-amino-6-(2'-aminophenyl-1,2,4- 
triazin-5(4H)-one (2) in view of their antifungal activity.

\section{Chemistry}

3-(Amino)-6-(2'-aminophenyl)-1,2,4-triazin-5(4H)-one (2) prepared by aminolysis of 3-mercapto-6-(2'-aminophenyl)-1,2,4-triazin-5(4H)-one (1) [10] in reflux ethanol. Condensation of compound 2 with 2-hydroxybenzaldehyde (1:2 by moles) in reflux ethanol yielded the arylidene derivative 3 which underwent cycloaddition with thioglycolic acid in reflux dioxan afforded the 4-thiazolidinone 4. Fluoroalkylation of compound 4 by reflux with ethyl trifluoroacetate in THF furnished 3-[(4'-oxo-2'-aryl-)-5-(trifluoroacetyl)thiazolidin-3'-yl]-6-[(2'-4"oxo-2-aryl-5"-trifluoroacetyl)-thiazolidin-3'-yl]phenyl]-1,2.4-triazin-5(4H)-one

(5) (Scheme 1). Fluoroalkylation of compound 4 takes the place of active methylene $\left(\mathrm{COCH}_{2}\right)$ rather than of $\mathrm{NH}$ proton of 1,2,4-triazinone.

\section{Results and Discussion}

Former structure of compound 2 deduced from correct elemental and spectral data. The IR absorption spectrum showed $v$ at $3200,3100(\mathrm{NH}, \mathrm{NH}), 3080$ $\left(\mathrm{NH}_{2}\right), 1670(\mathrm{C}=\mathrm{O})$ and 1630 (deformation of $\left.\mathrm{NH}_{2}\right) \mathrm{cm}^{-1}$. The ${ }^{1} \mathrm{HNMR}$ spectrum recorded $\delta$ at 13.4, 5.5 and $3.5 \mathrm{ppm}$ attributed to $\mathrm{NH}$ (1,2,4-triazine) and two $\mathrm{NH}_{2}$, with aromatic protons $\delta 7.68-6.9 \mathrm{ppm}$. The ${ }^{13} \mathrm{C}$ NMR spectrum give us a good indication, that showed $\delta$ at $172.95,147.62,147.24 \mathrm{ppm}$ for CO and two C-NH$H_{2}$. Also, $\delta$ at $115.48,114.87$ and $114.75 \mathrm{ppm}$ for carbon of 1,2,4-triazine.

IR spectrum of compound 3 recorded a lack both $\mathrm{NH}_{2}$ functional groups, Also that ${ }^{1} \mathrm{HNMR}$ showed a lack $\mathrm{NH}_{2}$ protons, with the presence of $\delta$ at $8.03,8.01 \mathrm{ppm}$ for two $\mathrm{N}=\mathrm{CH}$ protons. On the other hand, ${ }^{1} \mathrm{H}$ NMR spectrum of compound 4 showed a resonated $\mathrm{CH}_{2}$ protons at $\delta 2.68 \mathrm{ppm}$ which lack's in its of compound 5, which confirm that fluoroalkylation lack's place at $\mathrm{CH}_{2}$ and not $\mathrm{NH}$ position. The IR spectrum of 5 showed mainly $v$ at $1250 \mathrm{~cm}^{-1}$ for C-F. The ${ }^{13} \mathrm{CNMR}$

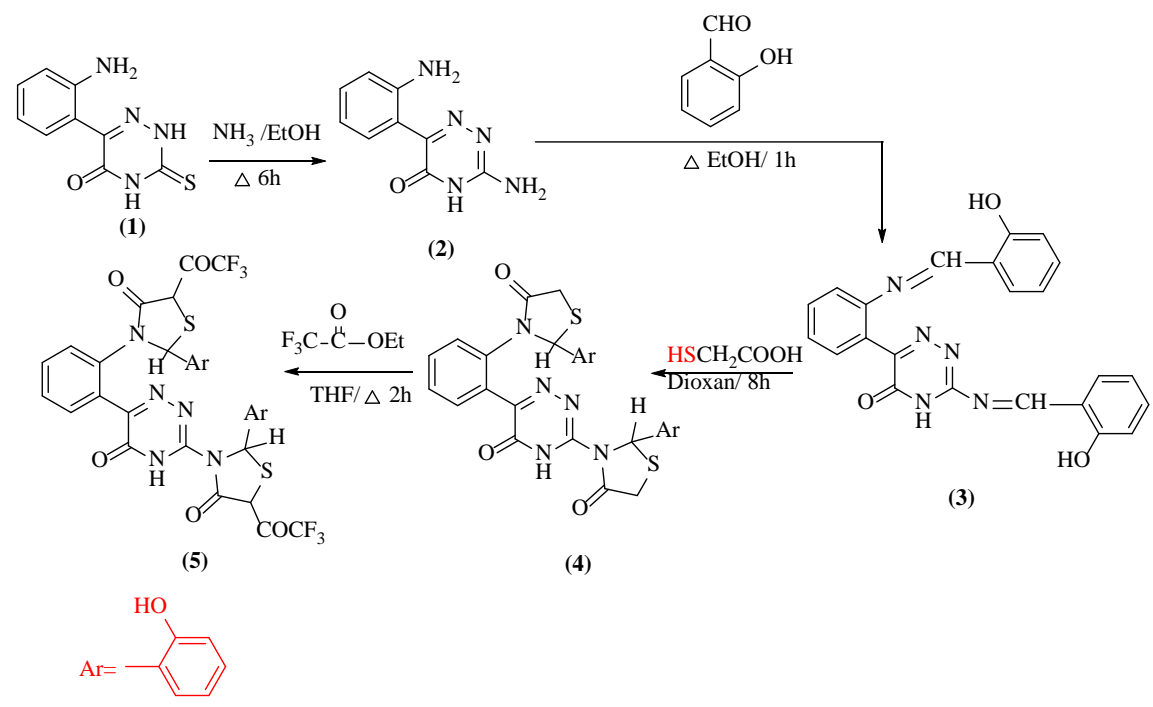

Scheme 1. Synthesis of compounds 2-5. 
spectrum of 5 exhibited a resonated signal at $149 \mathrm{ppm}$ attribute to $\mathrm{C}-\mathrm{F}$ carbons atom, with $\delta$ at $162,158 \& 152$ for $3 \mathrm{C}=\mathrm{O}$ and $\delta$ at $23 \mathrm{ppm} \mathrm{CH}$ aliphatic.

\section{Experimental}

The melting points determined on Gallen-Kamp melting point apparatus and are uncorrected. The infrared (IR) spectra recorded on Perkin-Elmer model RXI-IR 55529. ${ }^{1} \mathrm{H}$ and ${ }^{13} \mathrm{C}$ NMR spectra recorded on a BurkerDPX-400 FT NMR spectrometer using tetramethylsilane as the standard internal and DMSO- $\mathrm{d}_{6}$ as solvent (chemical shift in $\delta$, ppm). Spilling patterns designated as follows: $\mathrm{s}$, singlet; d, doublet; m, multiplet. Elemental analysis performed on 2400 Perkin Elmer series 2 analyzer. Direct-MS spectra carried out using quadruple MS (Electronic ionization mod El mode with source temperature: $200^{\circ} \mathrm{C}$ ) at $70 \mathrm{eV}$.

\subsection{3-Amino-6-(2'-Aminophenyl)-1,2,4-Triazin-5(4H)-One (2)}

To compound 1 (5 gm), liquid ammonia (39\%, $50 \mathrm{ml})$, in abs. EtOH (100 ml), refluxed for $6 \mathrm{~h}$, cooled. The resulted solid, filtered off and crystallized from $\mathrm{EtOH}$ to give 2. Yield $80 \%$, mp: $213^{\circ} \mathrm{C}-216^{\circ} \mathrm{C}$. IR $(v) \mathrm{cm}^{-1}: 3200,3100(\mathrm{NH} \&$ $\mathrm{NH}), 3080\left(\mathrm{NH}_{2}\right), 3020(\mathrm{Ar}-\mathrm{CH}), 1670(\mathrm{C}=\mathrm{O}), 1630$ (deformation of $\left.\mathrm{NH}_{2}\right), 820(o-$ substituted phenyl). ${ }^{1} \mathrm{H}$ NMR (DMSO- $\mathrm{d}_{6}$ ) $\delta$ ppm: 13.4, 5.5 and 3.5 (each s of 3 $\mathrm{NH}$ of 1,2,4-triazine), $7.68-6.9\left(\mathrm{~m}, 4 \mathrm{H}\right.$, aromatic protons), ${ }^{13} \mathrm{C} \mathrm{NMR}$ $\left(\mathrm{DMSO}_{6} \mathrm{~d}_{6}\right) \delta$ ppm: $172.95(\mathrm{C}=\mathrm{O}) .147 .62(\mathrm{C}=\mathrm{N}), 147.24,145\left(\right.$ two $\left.\mathrm{C}-\mathrm{NH}_{2}\right)$, 115.48, 114.87.114.75 (aromatic carbons). Analytical data, Calcd, C, 53.20; H, 4.43; N, 34.48\% for $\mathrm{C}_{9} \mathrm{H}_{9} \mathrm{~N}_{5} \mathrm{O}$ (203). Found: C, 52.98; N, 4.20; N, 4.20; N, 34.13\%.

\subsection{The Schiff Base 3}

A mixture of $2(0.01 \mathrm{~mol})$ and 2-hydroxybenzaldehyde $(0.02 \mathrm{~mol})$ in abs. EtOH $(100 \mathrm{ml})$ refluxed for $1 \mathrm{~h}$, cooled. The yielded solid, filtered off and crystallized from EtOH to give 3. Yield $81 \%$, mp: $198^{\circ} \mathrm{C}-202^{\circ} \mathrm{C}$. IR $(v) \mathrm{cm}^{-1}: 3500(\mathrm{OH})$, $3120(\mathrm{NH}), 1610,1580(\mathrm{C}=\mathrm{N}), 1660(\mathrm{C}=\mathrm{O}), 850$ (o-substituted phenyl). ${ }^{1} \mathrm{H}$ NMR (DMSO-d $\left.{ }_{6}\right) \delta$ ppm: 11.55 ( $s, \mathrm{IH}, \mathrm{NH}$ of 1,2,4-triazinone), 8.03, 8.01(two $\mathrm{N}=\mathrm{CH}$ ). 7.2 - 6.9, 6.7 - 6.5, 6.4 - 6.11(each $m, 12 \mathrm{H}$, aromatic protons). Analytical data, Calcd, C, 67.15; H, 4.13; N, 17.03\% for $\mathrm{C}_{23} \mathrm{H}_{17} \mathrm{~N}_{5} \mathrm{O}_{3}$. Found: C, 66.89; H, 4.01; N, $16.75 \%$.

\subsection{3-(4-0xo-Thiazolidin-3'-yl)-6-(2'-(4-0xo-Thiazolidin-3'-yl) Phenyl-1,2,4-Triazin-5(4H)-One (4)}

A mixture of $3(0.01 \mathrm{~mol})$ and thioglycolic acid $(20 \mathrm{ml})$ in dioxan $(100 \mathrm{ml})$ refluxed for $8 \mathrm{~h}$ cooled then poured onto ice. The produced solid, filtered off and crystallized from dioxane to give 4 . Yield $70 \%$, m.p: $187^{\circ} \mathrm{C}-190^{\circ} \mathrm{C}$. IR $(v) \mathrm{cm}^{-1}$ : 3500 - 3400 (b, OH, OH), $3120(\mathrm{NH}), 3030$ (aromatic $\mathrm{CH}$ ), 2980 (aliphatic $\mathrm{CH}_{2}$ ), 1680 - $1660\left(\mathrm{C}=\mathrm{O}\right.$ ), 1380(cyclic NCSC), 1440 (deformation $\mathrm{CH}_{2}$ ), 900, 820 (o-substituted phenyl). Analytical data, Calcd, C, 57.96; H, 3.75; H, 3.75; N, 12.52; S, 11.44\% for $\mathrm{C}_{27} \mathrm{H}_{21} \mathrm{~N}_{5} \mathrm{~S}_{2} \mathrm{O}_{5}(559)$. Found: C, 57.77; H, 3.55; N, 12.31; S, 
$10.98 \%$.

\subsection{3-[(4'-0xo-2'-(2"-Hydroxyphenyl)-5"-}

(Trifluoroacetylthiazolidin-3'-yl]-6-(2'-(4"-oxo-2"(2'"-Hydroxyphenyl)-5"-(Trifluoroacetyl)-Thiazolidin-3'-yl) Phenyl-1,2,4-Triazin-5(4H)-One (5)

A mixture of $4(0.01 \mathrm{~mol})$ and ethyl trifluoroacetate $(0.02 \mathrm{~mol})$ in THF $(100 \mathrm{ml})$ refluxed for $1 \mathrm{~h}$, cooled then poured on to ice. The resulted solid, filtered off and crystallized from THF to give 5 . Yield $60 \%$, mp: $244^{\circ} \mathrm{C}-247^{\circ} \mathrm{C}$. IR $(v) \mathrm{cm}^{-1}: 3500$ - 3400 (b, OH, OH), $3110(\mathrm{NH}), 3015$ (aromatic CH), 2880 (aliphatic CH), 1710, 1700, 1680 (3 C=O), 1660 - 1650 (2 C=O of thiazolidin-4'-one), 1440 (deformation $\mathrm{CH}$ ), 1350 (cyclic NCSC), 1250 (C-F), 910, 880,820 (o. substituted phenyl). ${ }^{1} \mathrm{H}$ NMR (DMSO-d $\left.\mathrm{d}_{6}\right) \delta$ ppm: $12.0(s, 1 \mathrm{H}, \mathrm{NH}$ of triazine), $8.8-8.66,7.12-7.00$, $6.90-6.70$ (each $m, 12 \mathrm{H}$, aromatic $\mathrm{H}), 4.8\left(2 \mathrm{H}, \mathrm{CH}-\mathrm{S}\right.$ of thiazolidinone). ${ }^{12} \mathrm{C}$ NMR(DMSO-d $\left.{ }_{6}\right) \delta$ ppm: 162(C=O), 158(C=O), 152(C=O), 149(C-F), 142(C=N of 1,2,4-triazine), 132-112 (aromatic carbons), 98 (C-S). Analytical data, Calcd C, 49.53; H, 2.52; N, 9.32; S, 8.52\% for $\mathrm{C}_{31} \mathrm{H}_{19} \mathrm{~F}_{6} \mathrm{~N}_{5} \mathrm{O}_{7} \mathrm{~S}_{2}$ (751): Found C, 49.08; $\mathrm{H}$, $2.32 ; \mathrm{N}, 9.11 ; \mathrm{S}, 8.09 \% . \mathrm{M} / \mathrm{S}\left(752, \mathrm{M}^{+2}, 5 \%\right), 141(100)$ as $\mathrm{COCSF}_{3} \mathrm{~N}$ (Figure 1).

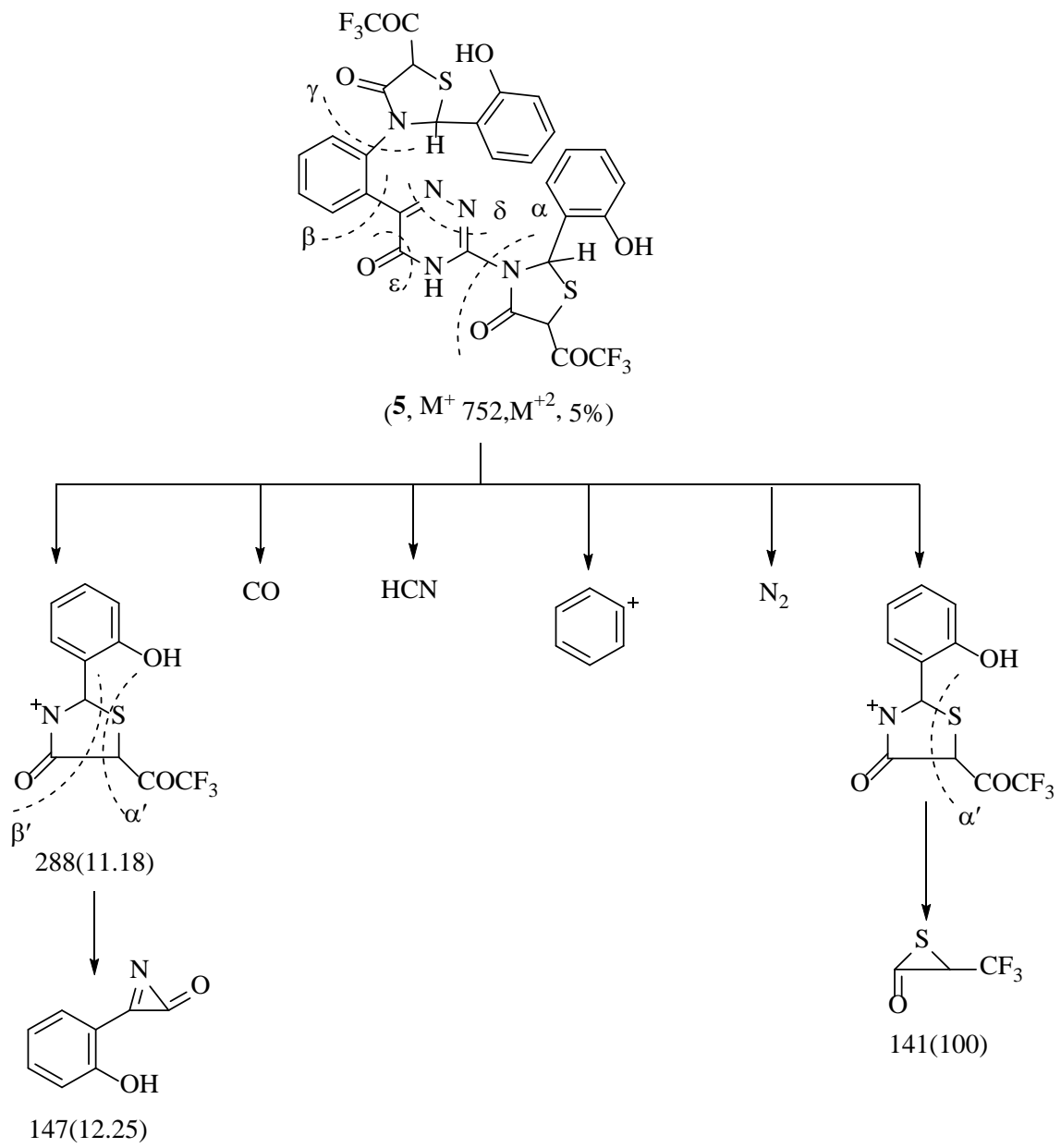

Figure 1. Mass fragmentation pattern of compound 5. 
Table 1. The antifungal activity of the un/fluorinated systems (4 \& 5). Control used: DMF (30\% germination).

\begin{tabular}{ccc}
\hline Compound & Concentration $\mu \mathrm{g} / \mathrm{mL}$ & $\begin{array}{c}\text { \% Germination in so if infested } \\
\text { with fungi }\end{array}$ \\
\hline \multirow{2}{*}{4} & 500 & 65 \\
& 1000 & 70 \\
5 & 500 & 78 \\
& 1000 & 80 \\
\hline
\end{tabular}

\section{Antifungal Evaluation}

Firstly, in vitro, the newly prepared compounds were assayed against the growth of some phytopathogenic fungi associated with what grains, i.e. Fusarium moniliforme. The assay performed by incorporating the tested compounds with nutrient agar at different concentration. The compounds dissolved in DMF and distilled water. The poisoned media were poured into sterile Petri-dishes and allowed to solidify. Each dish inoculated with a $4 \mathrm{~mm}$ diameter disk of inoculum removed from a 7 day old culture of the tested pathogens. Other media supplemented with DMF serving as a control. Treatment replicated 3 times, and the plates incubated at $27^{\circ} \mathrm{C}$.

Growth on the compound amended media determined by men swing colony diameter $(\mathrm{cm})$ and growth inhibition calculated with reference to the control. $\mathrm{ED}_{50}$ values determined by regression analysis of the long probit transformed data [11] [12]. From the result obtained show that compounds 5 and $\mathbf{4}$ are the most effective against the tested fungi. A higher effect of these compounds is may be due to containing fluorine atoms and/or 4-thiazolidinone moiety (Table 1).

Secondly, in vivo, the compound $\mathbf{5}$ has highest protecting activity on the grains (Tritium aestivum C.V Giza lss) of wheat against the fungal infection and increases the wheat germination compared with untreated grains. The best control of the used fungi achieved by $1000 \mathrm{mg} / \mathrm{ml}$ of compound 4 (704. Germination).

\section{Conclusion}

The fluorine substituted 4-thiazolidinone bearing 1,2,4-triazinone synthesized and compared with non-fluorinated were the fluorinated systems 5 exhibits highest germination (more plant protection) than the non-fluorinated systems 4 (lower plant protection).

\section{References}

[1] Abdel-Rahman, R.M. (2001) Chemoselective Heterocyclization and Pharmacological Activities of New Heterocycles-A Review. Part V-Synthesis of Biocidal 4-Thiazolidinones Derivatives. Bollettino Chimico Farmaceutico, 140, 401-410. https://www.ncbi.nlm.nih.gov/labs/articles/11822229/

[2] Kamila, S., Ankati, H. and Biehl, E.R. (2011) An Efficient Microwave Assisted Synthesis of Novel Class of Rhodanine Derivatives as Potential HIV-1 and JSP-1 Inhi- 
bitors. Tetrahedron Letters, 52, 4375-4377.

https://www.sciencedirect.com/science/article/pii/S0040403911008835

https://doi.org/10.1016/j.tetlet.2011.05.114

[3] Zakia, M.T., Abdel-Rahman, R.M. and El-Sayed, A.Y. (1995) Use of Arylidenerhodanines for the Determination of $\mathrm{Cu}(\mathrm{II}), \mathrm{Hg}(\mathrm{II})$ and $\mathrm{CN}^{-}$. Analytica Chimica Acta, 307, 127-138. https://www.sciencedirect.com/science/article/pii/0003267095000485 https://doi.org/10.1016/0003-2670(95)00048-5

[4] Abdel-Rahman, R.M., Makki, S.T., Ali, T.A. and Ibrahim, M.A. (2013) 1,2,4-Triazine Chemistry Part III: Synthetic Strategies to Functionalized Bridgehead Nitrogen Heteroannulated 1,2,4-Triazine Systems and their Regiospecific and Pharmacological Properties. Current Organic Synthesis, 10, 136-160.

[5] Abu Thaher, B.A., El-Abadla, N.S., Abdel-Rahman, R.M. and EL-Nwairy, K.A. (2009) Synthesis of Dihydro-1,2,4-Triazin-6-One Containing Nitroarginine Moiety. Journal of Natural and Engineering Studies, 17 1-10. http://journals.iugaza.edu.ps/index.php/IUGNS/article/view/114

[6] Abdel-Rahman, R.M., Makki, S.T., Ali, T.E. and Ibrahim, M.A. (2015) 1,2,4-Triazine Chemistry Part IV: Synthesis and Chemical Behavior of 3-Functionalized 5,6-Diphenyl-1,2,4-Triazines towards Some Nucleophilic and Electrophilic Reagents. Journal of Heterocyclic Chemistry, 52, 1595-1607.

http://onlinelibrary.wiley.com/doi/10.1002/jhet.2014/full https://doi.org/10.1002/jhet.2014

[7] Makki, S.T., Abdel-Rahman, R.M and Abu Ali, O.A. (2015) Synthesis of New Fluorinated 1,2,4-Triazino[3,4-b][1,3,4]Thiadiazolones as Antiviral Probes-Part II-Reactivities of Fluorinated 3-Aminophenyl-1,2,4-Triazinothia-Diazolone. International Journal of Organic Chemistry, 5, 153-165. https://doi.org/10.4236/ijoc.2015.53017

[8] Ali, T.E. and Abdel-Rahman, R.M. (2014) Synthesis and Antioxidant Activities of Some Novel Fluorinated Spiro[Oxindole-Thiazolidine] Fused with Sulfur and Phosphorus Heterocycles. Journal of Sulfur Chemistry, 35, 399-411. https://doi.org/10.1080/17415993.2014.896363

[9] Abdel-Rahman, R.M and Ali, T.E. (2013) Synthesis and Biological Evaluation of Some New Polyfluorinated 4-Thiazolidinone and a-Aminophosphonic Acid Derivatives. Monatshefte für Chemie-Chemical Monthly, 144, 1243-1252. https://link.springer.com/article/10.1007/s00706-013-0934-6 https://doi.org/10.1007/s00706-013-0934-6

[10] Abdel-Rahman, R.M. (1991) Synthesis and Anti-Human Immune Virus Activity of Some New Fluorine-Containing Substituted-3-Thioxo-1,2,4-Triazin-5-Ones. Farmaco (Societa Chimica Italiana: 1989), 46, 379-389.

[11] Finny, D.J. (1952) Estimation of the Median Effective Dose-Response Curve. Chapter 3, Probit Analysis, Cambridge University Press, New York, 20-48.

[12] Samra, A.S. (1956) Relative Value and Mode of Action of Some Fungicides Used as Seed Disinfectants and Protectants. Ph.D. Thesis, Wageningen Agricultural University, Wageningen. 